\title{
TARSIL AS AN EDUCATIONAL VALUE IN INDONESIAN SPORTS SYSTEM
}

\author{
Zainudin Amali ${ }^{1}$, Sumaryanto Sumaryanto ${ }^{2}$, Mohammad Arif Ali ${ }^{3}$ *, Gustiana Mega Anggita ${ }^{3}$, \\ Billy Castyana ${ }^{3}$, Tandiyo Rahayu ${ }^{3}$, Yusuf Suparman ${ }^{1}$, Heny Setyawati ${ }^{3}$, Said Junaidi ${ }^{3}$, \\ Donny Wira Yudha Kusuma ${ }^{3}$ \\ ${ }^{1}$ Ministry of Youth and Sports Republic of Indonesia, Jakarta, Indonesia \\ ${ }^{2}$ Universitas Negeri Yogyakarta, Yogyakarta, Indonesia \\ ${ }^{3}$ Universitas Negeri Semarang, Semarang, Indonesia \\ *e-mail: hiarifalikhan@mail.unnes.ac.id
}

\begin{abstract}
The implementation of national sports development must be in line with the national sports policies. TARSIL which is an abbreviation for trust, authority, responsibility, supervision, integration and local wisdom is considered as an ideal formula for policy making-regional autonomy related. The purpose of this study was to analyze the Indonesian Sports System (policy product) based on TARSIL values. This is a qualitative study whereby data were collected through observation, documentation, and interview. The Indonesian Sports System was used as the object of sports policy. Seven people actively participated in this study. Data analysis consisted of reduction, presentation, and conclusion drawing. The results showed that the Indonesian Sports System has been implementing TARSIL values. All components of TARSIL are stated in the Indonesian Sports System. However, not all indicators of those components were stated. We suggested that TARSIL values may be used as the consideration for the upcoming sports policies at either national or regional levels.
\end{abstract}

Keywords: Sports system, TARSIL values, educational value

\section{TARSIL SEBAGAI SEBUAH NILAI PENDIDIKAN DALAM SISTEM KEOLAHRAGAAN INDONESIA}

\begin{abstract}
Abstrak: Pelaksanaan pembangunan olahraga harus sesuai dengan kebijakan olahraga nasional. Di sisi lain, TARSIL yang terdiri atas komponen kepercayaan, wewenang, tanggung jawab, pengawasan, integrasi, dan kearifan lokal dianggap sebagai rumus ideal untuk pengambilan kebijakan yang terkait otonomi daerah. Oleh karena itu, tujuan dari penelitian ini adalah untuk menganalisis Sistem Keolahragaan Nasional sebagai produk kebijakan berdasarkan nilai-nilai TARSIL. Penelitian ini merupakan penelitian kualitatif. Sistem Keolahragaan Nasional digunakan sebagai objek kebijakan olahraga dan tujuh orang telah berpartisipasi aktif dalam penelitian ini. Pengumpulan data dilakukan melalui observasi, dokumentasi, dan wawancara. Analisis data terdiri dari reduksi data, penyajian data, dan penarikan kesimpulan. Hasil penelitian menunjukkan bahwa Sistem Keolahragaan Nasional telah menerapkan nilai-nilai TARSIL. Seluruh komponen TARSIL tertuang dalam sistem olahraga nasional. Namun tidak semua indikator dari komponen tersebut dicantumkan. Nilai-nilai TARSIL dapat digunakan sebagai bahan pertimbangan untuk membuat kebijakan olahraga yang akan datang baik di tingkat nasional maupun regional.
\end{abstract}

Kata Kunci: Sistem olahraga, nilai TARSIL, nilai pendidikan

\section{INTRODUCTION}

Decentralization in the form of regional autonomy implemented in Indonesia has been applied since the independence. The issue of deregulation and simplification in the reconstruction implementation of regional autonomy is necessary. The regional autonomy aims to implement the authority running effectively, efficiently, following the expectations of the constitution to improve the quality and equitable public services (Huda, 2014; Pratama, 2016). There are various obstacles in the implementation and the development of regional autonomy: (1) regional autonomy is not assessed as a continuous process, but as an output of the need for change; (2) the inability of political resources and local government in maximizing regional autonomy; and (3) the failure of regional autonomy in adapting to a good governance (Hrebiniak, 2006; Sullivan et al., 2018). In line with these obstacles, a case study showed that there are two challenges of regional autonomy (Ngakan et al., 2007). Clarity of authority between the central government and local governments as well as the commitment 
between the two must be maintained in carrying out the main tasks and functions (Ngakan et al., 2007).

Diversity in sports is real and each sport has their own regulations. Proper regulation is needed when it comes to bigger events or national sports development. Indonesian sports' policy was constructed in order to sustain and improve health and fitness, achievement, human quality; invest moral and behavioral values, fairness, and discipline; strengthen the unity of the nation, hold national defense, as well as improve the dignity and honor of the nation. It aims to develop the nation's physical abilities, mental and social behavior (Hughes et al., 2017; Song \& Zhang, 2018; Wise \& Kohe, 2020). There are eight principles of how to organize sports-related issues: (1) democratic, no discriminating and idolizing the values of religion, culture, and diversity; (2) social justice and humanity; (3) being fair and upholding the ethics and aesthetic; (4) cultivation and openness; (5) development of healthy lifestyle for society; (6) empowerment of society participation; (7) safety and security, and 8) wholeness between body and mental (Logan \& Cuff, 2019; Životić \& Veselinović, 2016).

Sport is part of the process and achievement of national development goals. The role of sport in national development is to develop physical, spiritual, and social abilities and shape noble character and personality of the nation. Therefore, the development of human resources is an important factor in the development of national sports. Education is a determining factor in achieving quality and character of human resources. The correct formula to construct a new policy is necessarily needed. Regardless of what the policy is related to, TARSIL is a suitable formula as an alternative to answering problems in the implementation of regional autonomy. The TARSIL model focuses on strengthening the central and regional governments' vertical relationship through 6 main indicators: Trust, Authority, Responsibility, Supervision, Integration, and Local Wisdom (Amali, 2019). TARSIL values is an appropriate formula to work out national sports policies in achieving national development goals. TARSIL values provides a solution in regulating the rights and obligations of central and local governments in carrying out all sports activities. Since sports have become the primary needs of human beings, ideally, any policy related to sports must be considered under the evaluation of TARSIL. Therefore, this study aimed to analyze the Indonesian Sports System (policy product) based on the TARSIL values.

\section{METHODS}

This is a qualitative study whereby data were collected through focus group discussion using the triangulation method, including observation, documentation and interview (Hammarberg et al., 2016) (de Lacey, 2016;). Due to the Coronavirus Disease (Covid-19) global pandemic, the interview was conducted online using a proprietary video teleconferencing software program (zoom). The data collection and analysis, data interpretation, and discussion was conducted from January 5th to May 25th, 2021. Meanwhile, the executive staff $(n=7)$ from the Ministry of Youth and Sports Affairs law department, as the subjects who participated actively in this study, were chosen using the snowball technique sampling. According to journalism ethics, at least three resources are required to clarify the truth of any information. Besides that, the Indonesian Sports System (Undang-Undang Republik Indonesia Nomor 3 Tahun 2005 tentang Sistem Keolahragaan Nasional also known as $U U S K N$ ) is used as the object of sports policy (Presiden Republik Indonesia, 2005).

The instrument of the study is based on TARSIL. TARSIL is the ideal formula to evaluate the National Sports Policy which consists of six components, namely Trust, Authority, Responsibility, Supervision, Integration, and Local Wisdom. Each component has indicators that describe the component specifically which is explained below.

The six indicators in trust that we defined to evaluate the national sports policy are: (1) opportunity (providing equal opportunities in making sports policy); (2) competence (sport policymaking requires the competence of the parties involved); (3) reliability (creation, implementation, and evaluation of sports policies involving various sports stakeholders); (4) respectfulness (the formulation and implementation of sports policies are carried out jointly between the center and the regions); (5) accountability (the formulation and implementation of sports policy are known to all stakeholders); and (6) identification of priorities (the creation and implementation of sports policies require the contribution of the central government and local governments in identifying priority needs).

The five indicators in authority that we defined to evaluate the national sports policy are: (1) sociological issues (socialization of sports 
policy is carried out to the whole community); (2) normative (settlement of sporting abuse and disputes is regulated in sports policy); (3) centralization and decentralization (sports policy regulates clear authority between the central government and local governments); (4) coordination (central government and local government communicate and coordinate in sports policy-making); and (5) independence (the involvement of components in the making and implementation of sports policies is regulated by each government).

The five indicators in responsibility that we defined to evaluate the national sports policy are: (1) contractualization (sports policies contain the rights and obligations of the central government and local governments); (2) opportunity and aspiration (sports policy to accommodate national sports development goals); (3) conditionality (sports policies direct the implementation of government programs for the realization of national sports development goals); (4) self-control (there is harmony in the implementation of sports policies at the center and in the regions); and (5) discipline (the central government and local governments determine the implementation of sports policies in a measurable and directed manner).

The six indicators in supervision that we defined to evaluate the national sports policy are: (1) communication (the central government and local governments have the same goal in making and implementing sports policies); (2) legislation and organizing (sports policies encourage the progress of national sports development); (3) regulation and planning (sport policy regulates the standard of sports administration): (4) inspection requirements (sports policy regulates the supervision of sports administration); (5) problem solving (sports policy regulates government and stakeholder involvement in sports dispute resolution); (6) evaluation (sports policy regulates evaluation standards for the implementation of sports standards).

The five indicators in integration that we defined to evaluate the national sports policy are: (1) identification (sports policies explain the development needs of national sports); (2) interaction (sports policy explains the synergy between the central government and local governments in making and implementing sports policies); (3) cooperation (sports policies regulate the collaboration of the central government and local governments in sports development); (4) solidarity (sports policies regulate the role of the central government and local governments in sports development); (5) positioning, (sports policy regulates the main tasks and functions of the central government and local governments in sports development).

The four indicators in local wisdom that we defined to evaluate the national sports policy are: (1) orientation (sports policies support the development of national sports by the capabilities of each region); (2) perception (sports policy regulates the determination of the leading sports of each region); (3) cultural adaptation (sports policies regulate the implementation of sports by the capabilities of each region), and (4) harmony (sports policies regulate the implementation of each local wisdom).

The qualitative analysis through three concurrent flows of activity data reduction, data display, and conclusion drawing/verification (Miles et al., 2014) was used to examine the results of interview, documentation, and observation.

\section{FINDINGS AND DISCUSSION}

\section{Findings}

TARSIL has six components namely Trust (the existence of mutual trust between the Central and Regional Governments), Authority (there is a commitment from each party in the delegation of authority), Responsibility (there is a responsibility to implement regulations consistently), Supervision (there is supervision from the Central Government on the implementation of regional autonomy policies), Integration (the existence of integration between systems that apply in the Central and Regional Governments), and Local Wisdom (there is a space for innovation and the application of local wisdom elements that are accommodated in the formulation of regional policies development). Based on the results of interviews and documentation, it was found that the components of TARSIL are contained in the Indonesian Sports System (UU SKN). The existence of TARSIL values is contained in articles and particles which are clearly written as shown in Table 1.

\section{Discussion}

Trust as a Bridge of Central and Local Government in Sport Development

Trust in the Indonesian Sports System is defined as the making and implementing of sports policies that require trust between the central government and local governments to align national sports development goals. In educational context, trust is one of the values that develop loyalty to their educational institutions (Carvalho $\&$ de Oliveira Mota, 2010). The opportunity is an 
indicator in trust (Puhakka \& Stewart, 2015). In the making and/or compiling of sports policies, it has been explicitly regulated regarding the duties, authorities, and responsibilities between the Central Government and Regional Governments. Thus, in the construction of sports policy, the Central Government and Regional Governments have the same duties, authorities, and responsibilities following their respective scope of duties, authorities, and responsibilities, of course with due regard to the objectives of national sports administration.

The making and or preparation of Sports Policy is certainly not only done internally. It requires support/assistance and synergy from parties who have competence (Schneider, 2019), including practitioners/academics/sports leaders and other elements who have concern and knowledge in the field of sports. In addition, at the technical level, competence is needed in the preparation/making of laws and regulations (legal drafting). This is in accordance with Law Number 12 of 2011 concerning the Establishment of Legislation and Regulation of the Minister of Empowerment of State Apparatus and Bureaucratic Reform (MABR) of the Republic of Indonesia Number Article 1 Number 5 concerning Functional Positions for Drafting Legislation and Credit Values (Presiden Republik Indonesia, 2014a).

Table 1. TARSIL Values in The Indonesian Sports System

\begin{tabular}{|c|c|c|c|}
\hline No & Component & Indicators & The Indonesian Sports System (UU SKN) \\
\hline \multirow[t]{6}{*}{1.} & Trust & Opportunity & $\begin{array}{l}\text { Article } 12 \text { Particle (1), Particle (2), Article } 13 \text { Particle (1), } \\
\text { Particle (2), and Article } 15\end{array}$ \\
\hline & & Competence & None \\
\hline & & Reliability & Article 75 Particle (1), Particle (2) and Particle (3) \\
\hline & & Respectfulness & $\begin{array}{l}\text { Article 12, Article 13, Article 15, and Article } 76 \text { Particle } \\
\text { (1) Particle (2) }\end{array}$ \\
\hline & & Accountability & Article 77 Particle (1) \\
\hline & & $\begin{array}{l}\text { Identification of Priori- } \\
\text { ties }\end{array}$ & Article 13, Article 34 Particle (2) \\
\hline \multirow[t]{5}{*}{2.} & Authority & Sociological & None \\
\hline & & Normative & Article 88 Particle (1), Particle (2), and Particle (3) \\
\hline & & $\begin{array}{l}\text { Centralization and de- } \\
\text { centralization }\end{array}$ & None \\
\hline & & Coordination & None \\
\hline & & Independence & None \\
\hline \multirow[t]{5}{*}{3.} & Responsibility & Contractualization & Article 11 Particle (1) Particle (2) \\
\hline & & $\begin{array}{l}\text { Opportunity and Aspi- } \\
\text { ration }\end{array}$ & Article 4, Article 5, and Article 42 \\
\hline & & Conditionality & Article 42 \\
\hline & & Self-control & Article 76 Particle (1) \\
\hline & & Discipline & None \\
\hline \multirow[t]{5}{*}{4.} & Supervision & $\begin{array}{l}\text { Communication } \\
\text { Legislation and organ- } \\
\text { izing }\end{array}$ & $\begin{array}{l}\text { Article } 4 \\
\text { the second line at general explanation }\end{array}$ \\
\hline & & $\begin{array}{l}\text { Regulation and plan- } \\
\text { ning }\end{array}$ & Article 81 Particle (1), Article 85 \\
\hline & & $\begin{array}{l}\text { Inspection require- } \\
\text { ments }\end{array}$ & Article 87 Particle (1), Article 113 \\
\hline & & Problem solving & Article 88 , Article 123 Particle (4) \\
\hline & & Evaluation & $\begin{array}{l}\text { Article } 81 \text { Article (1), Article } 86 \text { Particle (4), Article } 109 \\
\text { Particle (1) }\end{array}$ \\
\hline \multirow[t]{5}{*}{5.} & Integration & Identification & the second line at general explanation \\
\hline & & Interaction & Article 76 Particle (1) \\
\hline & & Cooperation & Article 76 Article (1) \\
\hline & & Solidarity & Article 12 , Article 13, and Article 15 \\
\hline & & Positioning & Article 3 , Article 12 \\
\hline \multirow[t]{4}{*}{6.} & Local Wisdom & Orientation & Article 13, Article 67 Particle (2), Article 77 Particle (3) \\
\hline & & Perception & Article 34 Particle (2) \\
\hline & & Cultural Adaptation & Article 4 \\
\hline & & Harmony & Article 34 Particle (1) \\
\hline
\end{tabular}


The reliability formally juridical in the formulation and/or policy-making, including the implementation and evaluation involving sports stakeholders (Edmond, 2012). Therefore, society is given the most comprehensive role in sporting activities, including the making of the policies through the instrument of public test/the aspirations collection/public consultation and or other media. Respectfulness as a juridical consequence of the government's duties, authorities, and responsibilities, in this case, the central government and regional governments (Province, Regency, and City). Therefore, the preparation, making, and implementation of sports policies are carried out jointly and coordinated following the scope of duties, authorities, and responsibilities with cooperation and partnership (Spagnoletti \& Arnold, 2007; van Quaquebeke, 2011).

Accountability is very important for government public body (Lindberg, 2013; Rached, 2016). The Ministry of Youth and Sports Affairs (MYSA) is qualified as a public body. According to Law Number 14, the Year 2008 concerning the Public Information Disclosure, this is a public body responsible for organizing affairs in the field of sports (Presiden Republik Indonesia, 2008). MYSA must provide access to information for sports stakeholders, including the construction of the preparation and/or making of sports policies. Identification of priorities is also trust component (Gardner et al., 1996). In the formulating and/or making policies, the Central Government and Regional Governments have inherent authority to formulate sports policies in the form of stipulating regulations of statutory regulations. Formulating and/or making the sports policies is carried out by setting a priority scale. In the grand design of national sports, the Government stipulates 14 leading sports and 1 sport (football) favored by the community, and this is following Presidential Instruction Number 3 the Year 2019 on the Acceleration of National Football Development. Meanwhile, the Regional Government is required to develop at least 1 (one) leading sport. Thus, the central and regional governments do not contribute but have an attributive authority as a drafter and/or sport policy maker according to the scope of their authority (Presiden Republik Indonesia, 2019).

\section{Authority for Sharing Powers in Sport Develop- ment}

Authority in the Indonesian Sports System is defined as the central government's powers to local governments which consist of mandatory, optional, and concurrent powers to make and implement sports policies. Authority is an educational value that is a fundamental component of classroom life and enacted through ongoing negotiations which often involves conflict that affects the balance of legitimacy and consent (Pace $\&$ Hemmings, 2007). The preparation and/or making of sports policies in the form of regulations starts from the planning stages of preparation, manufacture, determination and promulgation (dissemination). In the context of disseminating regulations in accordance with the provisions in the Presidential Decree Number 87 Year 2014 concerning the implementation of the Law Number 12 Year 2011 which deals with the formation of legislation, "promulgation" both in the form of government gazette and state gazette is the final stage of the process of making regulations (Presiden Republik Indonesia, 2011). Until this stage the principle of "legal fiction" applies, "When a statutory regulation has been promulgated, at that time everyone is considered to know "presumptio iures de iure" (HSB, 2017), and these provisions are binding so that someone's ignorance of the law cannot free/forgive him from lawsuits". This promulgation stage is a form of disseminating regulations either through socialization or other media. With the aim of stakeholders knowing the policies that the Central Government and Regional Governments have set. In terms of regulatory policies in the MYSA, the Documentation and Legal Information Network or Jaringan Dokumentasi dan Informasi Hukum (JDIH) is being used. It is accessible for the public at https://jdih.kemenpora.go.id.

The settlement of sports disputes in juridical construction is strictly regulated regarding the mechanism and stages of compensation (Robert $\&$ Zeckhauser, 2011). Centralization and decentralization (Alhamad \& Aladwan, 2019; Marume \& Jubenkanda, 2016), in making and/or formulating Sports Policy, the authority between the Central Government and the Regional Government has been explicitly regulated in the provisions of Article 10, Article 11, and Article 12 Government Regulations Number 16 the Year 2007 concerning the implementation of sports (Presiden Republik Indonesia, 2007). Furthermore, within the framework of implementing this authority, Law Number 23 the Year 2014 concerning The Regional Government has divided the authority for the administration of sports between the central, provincial, and district/city governments as listed in the Appendix for sports affairs which are mandatory non-basic services, 
so that the Central Government is required to prepare Norms, Standards, Procedures and Criteria or Norma, Standar, Prosedur, dan Kriteria (NSPK) as the reference and guideline for the Provincial and Regency Governments in carrying out sports affairs (Presiden Republik Indonesia, 2014b). The authority for sports affairs according to their respective scopes, is directed at realizing the objectives of organizing sports in a coordinated, integrated, and cooperative manner between the Central Government and Regional Governments (Osifo, 2013; Vanagas \& Stankevič, 2015). This follows the provisions in Article 17 Government Regulation Number 16 the Year 2007 concerning the Implementation of Sports. The formulation and or making of sports policies following the scope of authority of the Provincial and Regency Governments as stipulated in Article 10, Article 11, and Article 12 of Government Regulation Number 16 the Year 2007. This also involves sports stakeholders in their respective scopes according to the provisions in Article 10 Particle (3), Article 11 Particle (3), and Article 12 Particle (3) Government Regulation Number 16 the Year 2007. So, independent authority between government bodies is important (Burton \& Obel, 2018; Tsai, 2011).

\section{Responsibility to Meet Community's Need}

The Indonesian Sports System is defined as the formulation and implementation of sports policies is the responsibility of the local government to meet the community's response. This definition refers to the basis of legal provisions which are measurable, reliable, evaluative, and can be carried out as best as possible. Responsibility is an educational value that synergizes individual and community in education system to achieve common goals (Helker \& Wosnitza, 2014). Contractualization in sports policies that have been made and/or compiled by the Central Government and Regional Governments have juridical consequences in the form of rights and obligations (Baudry \& Chassagnon, 2018; Seli, 2021). Opportunity and aspiration in the context of sports policy are used to accommodate the national sports development goals (Baroudi et al., 2018; Zarestky \& Cole, 2017). It is legally stated in the considerations on the establishment of the Law of Indonesian Sports System that the national development instrument in the field of sports is an effort to improve the quality of life of Indonesian people physically, spiritually and socially in realizing an advanced, just, prosperous, prosperous and democratic society based on
Pancasila (Indonesian Ideology) and The Constitution of the Republic of Indonesia 1945 (Republik Indonesia, 1945). Furthermore, at the level of implementation of sports policies, it is directed that every sporting event (competition) organized by the Central Government, Regional Government, and the Community must pay attention to the national sports objectives and the principles of sports administration. The implementation of sports programs and/or activities including the holding of weekends (multi-events) and championships (single events) in the sports policy is principally an effort to support the achievement of "national development goals" through national development instruments in the field of sports (Kremmydas, 1989).

The implementation of sports policies following the respective scope of authority encourages synergy, cooperation, coordination, and continuous communication between the Central Government and Regional Governments in achieving national sports goals (Lian et al., 2017; Wang et al., 2021). This is strongly related to Article 17 in the Government Regulation Number 16 the Year 2007 concerning the implementation of sports. Therefore, the alignment and harmonization of the implementation of sports policies is an absolute thing that the Central Government and Regional Governments must do in their scope of authority. The determination of sports policies by the Government and Regional Governments is carried out in a measurable and directed manner following the Sports Strategic Plan Document in their respective scopes in a disciplined manner (Apalia, 2017), namely the national scope is determined by the Minister and Governor for the Provincial level and the Regent/Mayor for the Regency/ City Sports Strategic Plan. This is in accordance with the provisions in Article 44, Article 45, and Article 46 Government Regulation Number 16 the Year 2007 concerning the implementation of sports.

\section{Supervision in the Planning and Implementing Sports Policy}

Supervision in the Indonesian Sports System is defined as togetherness with the community. The central government is obliged to supervise the making and implementing of sports policies. Supervision is part of the education system that specifically has the role and responsibility to maintain and improve the quality of education (Haris et al., 2018). Planning aspects that are actualized in the National, Provincial, and Regency level Sports Strategic Plan documents with the 
aim of sporting policy directions made by the Government and Regional Governments are to be "measured and directed" to achieve national sports goals. An effective communication process can create a positive work environment and more effectively achieve the set goals (Hargie, 2016). The formulation of sports policies by the National and Regional Governments have the same goal in the context of realizing the "national sports goals". National sports aim to maintain and improve health and fitness, achievement, human quality, instill moral values and noble character, sportsmanship, discipline, strengthening and fostering national unity and integrity, strengthening national resilience, and elevating the nation's dignity and honor. The legislation becomes a catalyst to encourage organizations to work according to their functions (Jones, 2013). Sports policy is an instrument to encourage the achievement of national sports development progress. Sport is part of the process and achievement of national development goals. The existence and role of sport in society, nation, and state must be placed in a clear position in the national legal system. Regulation and change are an attempt by the government to control the behavior of citizens, companies, or local governments (Eisner et al., 2000). One of the sports policies regulates the authority of the Minister to determine the Standards for the Implementation of Sports which is one part of the National Standards for Sport.

Inspection requirements and conferencing, formulation and preparation of sports policies require aspects of supervision to run effectively, efficiently and have a strategic impact in achieving targets in the form of realizing national sports goals. The implementation of supervision is carried out in stages by the scope of authority, namely at the national level carried out by the Minister, the Governor at the Provincial level, and the Mayor for the Regency level. The national government, local government, and the community supervise the implementation of sports. Supervision of the sport implementation aims to ensure that the sport implementation runs by the planning and provisions of laws and regulations. An inspection is an independent and objective review of the organization's internal governance, management, and running. The inspection aims to determine the extent to which performance is being carried out, identify good practices and opportunities for improvement. Inspection functions to check the process, effectiveness, and efficiency of activities or policies (Joint Inspection Unit of the United Nations System,
2013). Problem solving and decision making is necessary in the internal deliberation of the parent organization of the sport did not reach an agreement. Mediation and arbitration are not achieved, so the settlement of sports disputes through the instrument of legal settlement institutions of the judiciary by their authority, which represents government institutions in terms of the "judicial" scope. Problem-solving focuses on rationality and rigorous analytical methods for rational policy-making (Turnbull, 2006).

\section{Integration between Government and Society in Sport Development}

Integration in the Indonesian Sports System is defined as the creation and implementation of sports policy involving central government, local government, and society intact. In education, integration is one of the values in an effort to achieve the competence of students, such as integrating the education curriculum and industry (Shaidullina et al., 2015). Identification (values and citizen interest) in sports policy in the context of encouraging the achievement of national sports goals is one of the instruments to achieve national development in the field of sports. Policy formulation principally involves identifying and analyzing various actions in response to each problem. Each solution found is assessed based on several factors such as possible effectiveness, potential costs, resources required for implementation, political context, and community support (Torjman, 2005). Communication in sports policies through the preparation and making of regulations encourage synergistic and sustainable cooperation and partnerships between the Central Government and Regional Governments by their scope of authority. The communication management framework in sports organizations involves the realization and implementation of the necessary processes. Communication ensures the creation, collection, segmentation, preparation, distribution, disbursement, and proper and complete use of key organizational information and available resources (Denkova \& Bajramovska, 2018). Cooperation and partnership is a form of synergy, collaboration, harmony, and coordination between the Central Government and the Regional Government in carrying out the duties, authorities, and responsibilities of sports development according to their respective scopes. Cooperation and participation mechanisms can be applied at different levels of the policy hierarchy, namely in developing and implementing policies, strategies, and overall concepts (Mulholland, 2018). 
Sports policy in juridical construction divides roles explicitly within the scope of sports coaching and development. The government has the task of establishing and implementing policies and standardization in the field of sports nationally. The local government has the charge of implementing policies, coordinating the coaching and development of sports, and implementing standardization in sports in the regions. The government has the authority to regulate, foster, develop, implement, and supervise the implementation of sports nationally. Regional governments have the authority to regulate, foster, develop, implement, and oversee the implementation of sports in the regions. Solidarity is not only legitimacy but an important thing for the community. Solidarity is a legal obligation, not just a political policy (Sangiovanni, 2012). The National Sports Goals have the function of developing physical, spiritual, and social abilities and shaping the character and personality of a dignified nation. Sporting positions are central to broader development practice. Sports positioning can use as a tool that must be applied holistically and integrated with other programs to achieve optimal results (The Sport for Development and Peace International Working Group (SDP IWG), 2008).

\section{Local Wisdom as a Basic Idea for Developing Sports}

Local Wisdom in the Indonesian Sports System is defined as local governments adopting reflections and expectations from the community in the formulation and implementation of sports policies. The meaning of local wisdom is associated with significant cultures in the region (Hidayat et al., 2017). Local wisdom is one of the fundamental values of education as a form of dynamic human culture so that exceptional humans are formed who remain oriented towards community culture (Darmadi, 2018). The values of local wisdom are matters that need to be considered in the formulation of sports policies. Furthermore, accommodating local wisdom in policy making is a strategic step to ensure the fulfillment of the objectives to be achieved through the prepared policies (Slamet, 2019). Alignment of the central and local governments' roles in implementing sports policies can support the development of national sports. The policy orientation can influence the environment and behavior (Stahl, 2002). Formulation and construction of sports policies to support national sports development by the authority of the Central and Regional Governments according to their capabilities, among others, are human resources, infrastructure and facilities as well as the financial capacity of each region. The central and local governments ensure the availability of sports infrastructure by the standards and needs of the central and local governments. Based on their authority and capabilities, local governments can develop and manage sports information by regional capabilities and conditions. Likewise, the ability of regions to allocate sports funding from the Regional Revenues and Expenditures Budget or Anggaran Pendapatan dan Belanja Daerah (APBD), of course, varies according to the financial capacity of each region in supporting the implementation of sports duties, authorities, and responsibilities.

Regional governments are required to manage at least one leading sport at a national and international level. This policy is factually in line with the direction of the national sports policy in the preparation of the National Sports Grand Design, which stipulates 14 (fourteen) priority sport and 1 (one) sport favored by the community. Perceptions of stakeholders can have an impact on the formulation of sports policy. It can contribute to the development of sports policies that can be applied at all levels of the organization (Viollet et al., 2016). The implementation of sports policies is an urgent and strategic matter to achieve national sports goals. National sports are aimed at maintaining and improving health and fitness, achievement, human quality, instilling moral values and noble character, sportsmanship, discipline, strengthening and fostering national unity and integrity, strengthening national resilience, and elevating the nation's prestige, dignity and honor, support, synergy, and collaboration between the Government and Regional Government are necessary by considering the capabilities and potential of each region. Formulation and construction of sports policies consider the local wisdom possessed by each region. District/city governments plan, foster, develop, implement standardization, and raise sports resources based on local excellence in harmony.

\section{CONCLUSION}

All components of TARSIL are contained in the Indonesian Sports System (policy product). However, not all indicators of these components have been stated. In conclusion, the Indonesian Sports System has implemented TARSIL values. Finally, we suggest TARSIL values as an ideal formula for policy-making related to regional autonomy that contains the educational value which can be taught and socialized to sports 
stakeholders and other related parties so that it can color future sports policies both at the national and regional levels. TRASIL components and indicators are educational values that can animate the entire Indonesian sports system.

\section{REFERENCES}

Alhamad, B. M., \& Aladwan, R. (2019).

Balancing centralization and decentralization management at University of Bahrain. Quality Assurance in Education, 27(2), 237-250. https://doi.org/10.1108/QAE-01-20180005

Amali, Z. (2019). Penyelenggaraan otonomi daerah perlu direkonstruksi. Desapedia.Id. https://www.desapedia.id/dr-zainudinamali-penyelenggaraan-otonomi-daerahperlu-direkonstruksi/

Apalia, E. A. (2017). Effects of discipline management on employee performance in an organization: The case of county education office human resource department, Turkana County. International Academic Journal of Human Resource and Business Administration, 2(3), 1-18. http://www.iajournals.org/articles/iajhrba _v2_i3_1_18.pdf

Baroudi, S. El, Khapova, S. N., Fleisher, C., \& Jansen, P. G. W. (2018). How do career aspirations benefit organizations? The mediating roles of the proactive and relational aspects of contemporary work. Frontiers in Psychology, 9. https://doi.org/10.3389/fpsyg.2018.02150

Baudry, B., \& Chassagnon, V. (2018). The analysis of employment relationship in contract economic theories: A critical review based on the nature of American and French Labor Laws. Économie et Institutions, 27. https://doi.org/10.4000/ei.6127

Burton, R. M., \& Obel, B. (2018). The science of organizational design: fit between structure and coordination. Journal of Organization Design, 7(1), 5. https://doi.org/10.1186/s41469-018-00292

Carvalho, S. W., \& de Oliveira Mota, M. (2010). The role of trust in creating value and student loyalty in relational exchanges between higher education institutions and their students. Journal of Marketing for

Higher Education, 20(1), 145-165.

https://doi.org/10.1080/088412410037882 01

Darmadi, H. (2018). Educational management based on local wisdom (Descriptive analytical studies of culture of local wisdom in West Kalimantan). JETL (Journal Of Education, Teaching and Learning), 3(1), 135. https://doi.org/10.26737/jetl.v3i1.603

Denkova, J., \& Bajramovska, M. (2018). The role of communication management in sports with special emphasis on handball. Journal of Process Management. New Technologies, 6(4), 35-40. https://doi.org/10.5937/jouproman619001

Edmond, G. (2012). Is reliability sufficient? The law commission and expert evidence in international and interdisciplinary perspective (Part 1). The International Journal of Evidence \& Proof, 16(1), 3065.

https://doi.org/10.1350/ijep.2012.16.1.391

Eisner, M. A., Worsham, J., \& Ringquist, E. J. (2000). Contemporary regulatory policy. Choice Reviews Online, 37(08), 37-460037-4600. https://doi.org/10.5860/CHOICE.37-4600

Gardner, J., Weinrib, E., \& Brudner, A. (1996). The purity and priority of private law. The University of Toronto Law Journal, 46(3), 459. https://doi.org/10.2307/825774

Hammarberg, K., Kirkman, M., \& de Lacey, S. (2016). Qualitative research methods: when to use them and how to judge them. Human Reproduction, 31(3), 498-501. https://doi.org/10.1093/humrep/dev334

Hargie, O. (2016). The importance of communication for organisational effectiveness. Psicologia Do Trabalho e Das Organizações, 15-32.

Haris, I., Naway, F., Pulukadang, W. T., Takeshita, H., \& Ancho, I. V. (2018). School supervision practices in the Indonesian education system; perspectives and challenges. Journal of Social Studies Education Research, 9(2), 366-387. https://dergipark.org.tr/en/pub/jsser/issue/ 37944/438306

Helker, K., \& Wosnitza, M. (2014). 
Responsibility in the school context-development and validation of a heuristic framework. Frontline Learning Research, 2(3), 115-139. https://doi.org/10.14786/flr.v2i2.99

Hidayat, S., Mutohir, T. C., \& Pramono, M. (2017). Development of trekking sports based on local wisdom in supporting tourism sport industry. 2nd International Conference on Sports Science, Health and Physical Education, 207-210. https://doi.org/10.5220/000705800207021 0

Hrebiniak, L. G. (2006). Obstacles to effective strategy implementation. Organizational Dynamics, 35(1), 12-31. https://doi.org/10.1016/j.orgdyn.2005.12. 001

HSB, A. M. (2017). Mengkritisi pemberlakuan teori fiksi hukum (criticising enactment of law fiction theory). Jurnal Penelitian Hukum De Jure, 16(3), 251. https://doi.org/10.30641/dejure.2016.V16. 251-264

Huda, N. (2014). Desentralisasi asimetris dalam negara kesatuan Republik Indonesia: Kajian terhadap daerah istimewa, daerah khusus dan daerah otonomi khusus. Nusa Media.

Hughes, H., Brandt, T., Devine, C., Rubin, J., Bonura, K. B., \& Galli, N. (2017). Diversity and inclusion in sport. Society for Sport, Exercise, \& Performance Psychology, 5(1).

Joint Inspection Unit of the United Nations System. (2013). Norms and standards for inspection, norms and standards for evaluation and general principles and guidelines for investigations. Joint Inspection Unit of the United Nations System.

Jones, K. K. (2013). The impact of legislation on the organization: Evaluating the impact of corporate governance regulation on the internal audit function. Georgia State University.

Kremmydas, N. (1989). The cross-conditionality phenomenon-some legal aspects. The International Lawyer, 23(3), 651-675.

Lian, H., Yam, K. C., Ferris, D. L., \& Brown, D. (2017). Self-control at work. Academy of Management Annals, 11(2), 703-732. https://doi.org/10.5465/annals.2015.0126
Lindberg, S. I. (2013). Mapping accountability: core concept and subtypes. International Review of Administrative Sciences, 79(2), 202-226. https://doi.org/10.1177/002085231347776 1

Logan, K., \& Cuff, S. (2019). Organized sports for children, preadolescents, and adolescents. Pediatrics, 143(6), e20190997. https://doi.org/10.1542/peds.2019-0997

Marume, S. B. M., \& Jubenkanda, R. R. (2016). Centralization and decentralization. Quest Journals: Journal of Research in Humanities and Social Science, 4(6). http://www.questjournals.org/jrhss/papers /vol4-issue6/Q46106110.pdf

Miles, M. B., Huberman, A. M., \& Saldaña, J. (2014). Qualitative data analysis: A methods sourcebook. Sage.

Mulholland, E. (2018). Cooperation between stakeholders and policymakers in the implementation of the SDGs: Overview of activities and practices in Europe. ESDN Quarterly Report, 50.

Ngakan, P. O., Achmad, A., Lahae, K., Komarudin, H., \& Tako, A. (2007). Implikasi perubahan kebijakan otonomi daerah terhadap beberapa aspek di sektor kehutanan: studi kasus di kabupaten Luwu utara, Sulawesi selatan. Center for International Forestry Research (CIFOR).

Osifo, O. C. (2013). The effects of coordination on organizational performance: An intra and inter perspective. Asian Journal of Business and Management, 1(4).

Pace, J. L., \& Hemmings, A. (2007). Understanding authority in classrooms: A review of theory, ideology, and research. Review of Educational Research, 77(1), 4-27. https://doi.org/10.3102/003465430298489

Pratama, A. Y. (2016). Pelaksanaan desentralisasi asimetris dalam tata kelola pemerintahan daerah di era demokrasi. Jurnal Ilmiah Pendidikan Pancasila Dan Kewarganegaraan, 28(1). https://doi.org/10.17977/jppkn.v28i1.5434

Presiden Republik Indonesia. (2005). UndangUndang Nomor 3 tahun 2005 tentang sistem keolahragaan nasional (No. 3). https://www.dpr.go.id/dokjdih/document/ $\mathrm{uu} / 45 . \mathrm{pdf}$ 
Presiden Republik Indonesia. (2007). Peraturan Pemerintah Republik Indonesia Nomor 16 Tahun 2007 tentang penyelenggaraan keolahragaan. Republik Indonesia. https://peraturan.bpk.go.id/Home/Details/ 4737/pp-no-16-tahun-2007

Presiden Republik Indonesia. (2008). UndangUndang Republik Indonesia Nomor 14 Tahun 2008 tentang keterbukaan informasi publik. Republik Indonesia. https://peraturan.bpk.go.id/Home/Details/ 39047/uu-no-14-tahun-2008

Presiden Republik Indonesia. (2011). UndangUndang Republik Indonesia Nomor 12 Tahun 2011 tentang pembentukan peraturan perundang-undangan. Republik Indonesia. https://bphn.go.id/data/documents/11uu01 2.pdf

Presiden Republik Indonesia. (2014a). Peraturan Presiden Republik Indonesia Nomor 87 Tahun 2014 tentang Peraturan Pelaksanaan Undang-Undang Nomor 12 Tahun 2011 tentang Pembentukan Peraturan Perundang-Undangan. Republik Indonesia. https://peraturan.bpk.go.id/Home/Details/ 41581/perpres-no-87-tahun-2014

Presiden Republik Indonesia. (2014b). UndangUndang Republik Indonesia Nomor 23 Tahun 2014 tentang pemerintahan daerah. Republik Indonesia. https://pih.kemlu.go.id/files/UU0232014. pdf

Presiden Republik Indonesia. (2019). Instruksi Presiden Republik Indonesia Nomor 3 Tahun 2019 tentang percepatan pembangunan persepakbolaan nasional. Republik Indonesia. https://peraturan.bpk.go.id/Home/Details/ 127665/inpres-no-3-tahun-2019

Puhakka, V., \& Stewart, H. (2015). Social creation of opportunities: breaking boundaries to create mutually attractive business. Journal of Innovation Economics, 18(3), 53. https://doi.org/10.3917/jie.018.0053

Rached, D. H. (2016). The concept(s) of accountability: form in search of substance. Leiden Journal of International Law, 29(2), 317-342. https://doi.org/10.1017/S09221565160000 42
Republik Indonesia. (1945). Undang-Undang Dasar Negara Republik Indonesia Tahun 1945. Sekretariat Jenderal MPR RI.

Robert, C., \& Zeckhauser, R. (2011). The methodology of normative policy analysis. Journal of Policy Analysis and Management, 30(3), 613-643. https://doi.org/10.1002/pam.20578

Sangiovanni, A. (2012). Solidarity in the European Union*. In Philosophical Foundations of European Union Law (pp. 384-411). Oxford University Press. https://doi.org/10.1093/acprof:oso/978019 9588770.003.0015

Schneider, K. (2019). What does competence mean? Psychology, 10(14), 1938-1958. https://doi.org/10.4236/psych.2019.10141 25

Seli, H. (2021). All you need to know about contractualization.

https://www.academia.edu/34230929/All_ You_Need_to_Know_About_Contractuali zation

Shaidullina, A. R., Pavlova, N. A., Minsabirova, V. N., Burdukovskaya, E. A., Yunusova, A. B., Letyaev, V. A., \& Afanasev, A. S. (2015). Integration processes in education: Classification of integration types. Review of European Studies, 7(4). https://doi.org/10.5539/res.v7n4p27

Slamet PH. (2019). Politik pendidikan Indonesia dalam Abad ke-21. Cakrawala Pendidikan, 11(2), 50-57. https://doi.org/10.21831/cp.v3i3.2377

Song, M., \& Zhang, Y. (2018). Research on the relationship between geographical factors, sports and culture. Advances in Physical Education, 08(01), 66-70. https://doi.org/10.4236/ape.2018.81008

Spagnoletti, C. L., \& Arnold, R. M. (2007). RE-S-P-E-C-T: Even more difficult to teach than to define. Journal of General Internal Medicine, 22(5), 707-709. https://doi.org/10.1007/s11606-007-0164$\mathrm{x}$

Stahl, T. (2002). The importance of policy orientation and environment on physical activity participation--a comparative analysis between Eastern Germany, Western Germany and Finland. Health Promotion International, 17(3), 235-246. https://doi.org/10.1093/heapro/17.3.235 
Sullivan, J. L., Adjognon, O. L., Engle, R. L., Shin, M. H., Afable, M. K., Rudin, W., White, B., Shay, K., \& Lukas, C. V. (2018). Identifying and overcoming implementation challenges: Experience of 59 noninstitutional long-term services and support pilot programs in the Veterans Health Administration. Health Care Management Review, 43(3), 193-205. https://doi.org/10.1097/HMR.0000000000 000152

The Sport for Development and Peace International Working Group (SDP IWG). (2008). Harnessing the power of sport for development and peace: recommendations to governments. Sportanddev.Org. https://www.sportanddev.org/en/article/pu blication/harnessing-power-sportdevelopment-and-peacerecommendations-governments

Torjman, S. (2005). What is policy? Caledon Institute of Social Policy.

Tsai, Y. (2011). Relationship between organizational culture, leadership behavior and job satisfaction. $B M C$ Health Services Research, 11(1), 98. https://doi.org/10.1186/1472-6963-11-98

Turnbull, N. (2006). How should we theorise public policy? Problem solving and problematicity. Policy and Society, 25(2), 3-22. https://doi.org/10.1016/S14494035(06)70072-8

van Quaquebeke, N. (2011). Defining respectful leadership. RSM Discovery-Management Knowledge, 5(1), 12-14.

Vanagas, R., \& Stankevič, J. (2015). Impact of coordination for organization process.
Intellectual Economics, 8(2), 112. https://doi.org/10.13165/IE-14-8-2-08

Viollet, B., Minikin, B., Scelles, N., \& Ferrand, A. (2016). Perceptions of key stakeholders regarding National Federation Sport Policy: The case of the French Rugby Union. Managing Sport and Leisure, 21(5), 319-337. https://doi.org/10.1080/23750472.2017.12 80837

Wang, Y.-J., Chen, K.-Y., Dou, K., \& Liu, Y.-Z. (2021). Linking self-control to voluntary behaviors at workplace: The mediating role of job satisfaction. Frontiers in Psychology, 12. https://doi.org/10.3389/fpsyg.2021.53029 7

Wise, N., \& Kohe, G. Z. (2020). Sports geography: new approaches, perspectives and directions. Sport in Society, 23(1), 110. https://doi.org/10.1080/17430437.2018.15 55209

Zarestky, J., \& Cole, C. S. (2017). Strengths, opportunities, aspirations, and results: An emerging approach to organization development. New Horizons in Adult Education and Human Resource Development, 29(1), 5-19. https://doi.org/10.1002/nha3.20166

Životić, D., \& Veselinović, J. (2016). The significance of the organizing process in sports organizations. Facta Universitatis, Series: Physical Education and Sport, 307-313. http://casopisi.junis.ni.ac.rs/index.php/FU PhysEdSport/article/view/1737 